Arq. Bras. Med. Vet. Zootec., v.68, n.6, p.1581-1585, 2016

\title{
Partial hepatectomy in a calf with an omphalocele: case report
}

\author{
[Hepatectomia parcial em bezerra portadora de onfalocele: relato de caso] \\ F.A. Lucas ${ }^{1}$, E.M. Panelli ${ }^{1}$ E. Nardin Neto ${ }^{1}$ A.L. Kandrotas ${ }^{1}$ S. Mastrocinque ${ }^{2}$, \\ R.A. Lataro $^{3}$ G.G.S. Oliveira ${ }^{2}$ \\ ${ }^{1}$ Faculdade de Medicina Veterinária de Araçatuba - UNESP - Araçatuba, SP \\ ${ }^{2}$ Centro Universitário Barão de Mauá - Ribeirão Preto, SP \\ ${ }^{3}$ Médica veterinária autônoma
}

\begin{abstract}
An omphalocele is a defect in the closure of the abdominal wall during the embryonic stage, preventing the return of some abdominal organs to the cavity. In stillborn animals, the involvement of the liver in the omphalocele has been reported. The aim of the present study is to report the success of a partial liver resection in a female bovine at two days of age which presented an omphalocele at birth. Surgical intervention was indicated to reduce and suture the abdominal wall. During the surgical procedure, the presence of hard, reddish tissue was noted inside the sac covered by the amniotic membrane, with characteristics consistent with hepatic parenchyma. Due to the impossibility of reducing the contents added to the suggestion of tissue infection, we elected to perform a partial resection. The histopathological examination confirmed that the resected tissue was of the hepatic parenchyma. Antibiotic and systemic anti-inflammatory therapies were performed post-surgery. Fifteen days after surgery, infection was detected at the surgical site in addition to abdominal wound dehiscence; surgical reintervention was performed. On physical examination, carried out 4 months after the second operation, the heifer presented normal development for the species. In conclusion, omphalocele may contain liver. Ectopic liver is an extremely rare condition. Surgical treatment in the presented case focused on umbilicus with exploration of the abdominal cavity appeared to be sufficient.
\end{abstract}

Keywords: cattle, liver resection, omphalocele

\section{RESUMO}

A onfalocele é um defeito no fechamento da parede abdominal durante a fase embrionária, não permitindo o retorno de alguns órgãos abdominais à cavidade. O envolvimento do fígado em onfalocele tem sido relatado, porém em animais natimortos. Com o presente estudo, objetiva-se relatar uma ressecção parcial do fígado realizada com sucesso em uma fêmea bovina com dois dias de idade apresentando onfalocele ao nascimento. Foi indicada a intervenção cirúrgica para a redução e rafia da parede abdominal. Durante o procedimento cirúrgico, notou-se, no interior do saco recoberto pela membrana amniótica, a presença de tecido firme, de coloração avermelhada, com características compatíveis com parênquima hepático. Devido à impossibilidade de redução do conteúdo e sugestão de infecção do tecido encontrado, optou-se pela ressecção parcial dele. $O$ exame histopatológico confirmou tratar-se de parênquima hepático o tecido resseccionado. No pós-cirúrgico, realizaram-se terapias antibiótica e antiinflamatória sistêmicas. Após 15 dias do procedimento cirúrgico, foi detectada infecção do sítio operatório e deiscência da sutura abdominal, sendo realizada reintervenção cirúrgica. No exame físico, realizado no animal após quatro meses da segunda intervenção cirúrgica, constatou-se desenvolvimento normal para a espécie. Conclui-se que o fígado pode ser conteúdo da onfalolocele, sendo uma condição extremamente rara. O tratamento cirúrgico no caso apresentado, com exploração da cicatriz umbilical e da cavidade abdominal, foi suficiente.

Palavras-chave: bovinos, ressecção hepática, onfalocele

\section{INTRODUCTION}

An omphalocele is a hernia or protrusion of the abdominal contents at the base of the umbilical

Recebido em 13 de novembro de 2015

Aceito em 12 de maio de 2016

E-mail: flavialucas@fmva.unesp.br cord (Kliegman and Behrman, 1987), being a rare congenital defect in the wall of the abdomen. It results from the failure of the intestine or other abdominal organs to return to the abdominal cavity during the initial stages of 
gestation (Moore, 1988). During the early stages of fetal development, the midgut is contained in the embryonic yolk sac outside of the coelom. Later, it returns to the abdominal cavity. The final closure of the abdominal wall in this process depends on the growth and fusion of the four body folds since they lie at the base of the umbilical cord (Wesley, 1997). Unlike an umbilical hernia, the coverage of the hernia sac in an omphalocele is the epithelium of the umbilical cord, a derivative of the amnion (Moore, 1988). The defect size determines the quantity and type of viscera found (Wesley, 1997).

The single cause of omphalocele is not known and it could be a defect in development, without necessarily being hereditary (Baird, 1993), although it has been suggested that it may be a recessive genetic trait (Ko et al, 1990).

Studies report that the mortality rates of calves affected by omphalocele are $55 \%, 9 \%$, and $36 \%$ in the pre-, intra-, and post-partum periods, respectively. According to Mee (1994), despite reports indicating that $74 \%$ of calves affected by omphalocele are females, it has been suggested that the genes responsible for umbilical hernia and omphalocele are not linked to sex.

After identification of the problem, the surgical treatment needs to be performed immediately, before infection or tissue damage occurs, and is therefore essential for survival (Kliegman and Behrman, 1987). Despite improvements in surgical techniques and neonatal intensive care, the mortality rate is 13 to 40 percent in human infants (Dunn and Fonkalsrub, 1997).

The aim of this study is to report the successful partial hepatectomy of a female calf with an omphalocele, the contents consisting of hepatic parenchyma.

\section{CASE REPORT}

A bovine crossbreed female, at two days of age presenting swelling in the umbilical region, observed at birth, was treated at the Veterinary Hospital of the Centro Universitário Barão de
Mauá, Ribeirão Preto (SP), Brazil. According to the owner, the delivery was normal and the mother did not have any health problems. On clinical examination, the presence of a mass of tissue, rounded, approximately $20 \mathrm{~cm}$ in diameter was noted, filling the remnant of the umbilical cord. The observed mass was covered with a thin membrane, slightly dry, isolating the contents from the external environment, not allowing visualization of its contents (Fig. 1A). On digital palpation firm consistency, irreducibility, and pain were noted.

Immediate surgical intervention to reduce the mass was indicated. The animal received Xylazine $\left(0.05 \mathrm{mg} \mathrm{kg}^{-1}\right)$ as preanesthetic medication (Rompum, Bayer SA, Saúde Animal, Brazil) and, fifteen minutes later, installation of a $16 \mathrm{G}$ catheter was performed in the jugular vein. Anesthesia was induced with ketamine $\left(2 \mathrm{mg} \mathrm{kg}^{-}\right.$ 1) (ketamine, Parke-Davis, Brazil), followed by maintenance of total intravenous anesthesia with xylazine $\left(0,1 \mathrm{mg} \mathrm{kg}^{-1}\right)$, ketamine $\left(2 \mathrm{mg} \mathrm{kg}^{-1}\right)$ and guaiacol glyceryl ether (50mg kg-1) (Guaiacol glyceryl ether, Henryfarma, Brazil), diluted in $5 \%$ glucose solution, an anesthetic technique also known as "triple drip", administered by continuous infusion. An elliptical skin incision was made around the volume increase, surrounding it, with subsequent divulsion of the subcutaneous tissue (Fig. 1B). After the incision of the membrane which covered the mass, the contents were noted, with the presence of a firm, reddish texture, with characteristics consistent with hepatic parenchyma, covered by dried amniotic membrane (Fig. 1C and 1D). Due to the impossibility of reducing the contents and the suggestion of the presence of tissue infection, we opted to resection the externalized mass, with ligation by transfixing the openings using polyglactin $910^{\mathrm{d}}$ number 0 . After excision, the removed mass was examined and was found to be similar to macroscopic liver tissue and a fragment was sent for histopathological examination (Fig. 1E and $1 \mathrm{~F}$ ). The abdominal sutures were performed using polyglactin $910^{\mathrm{d}}$ number 0 wire (Vicryl, Ethicon, Brazil) and standard lateral overlapping sutures and the subcutaneous tissue and skin with nylon wire number 0 . 


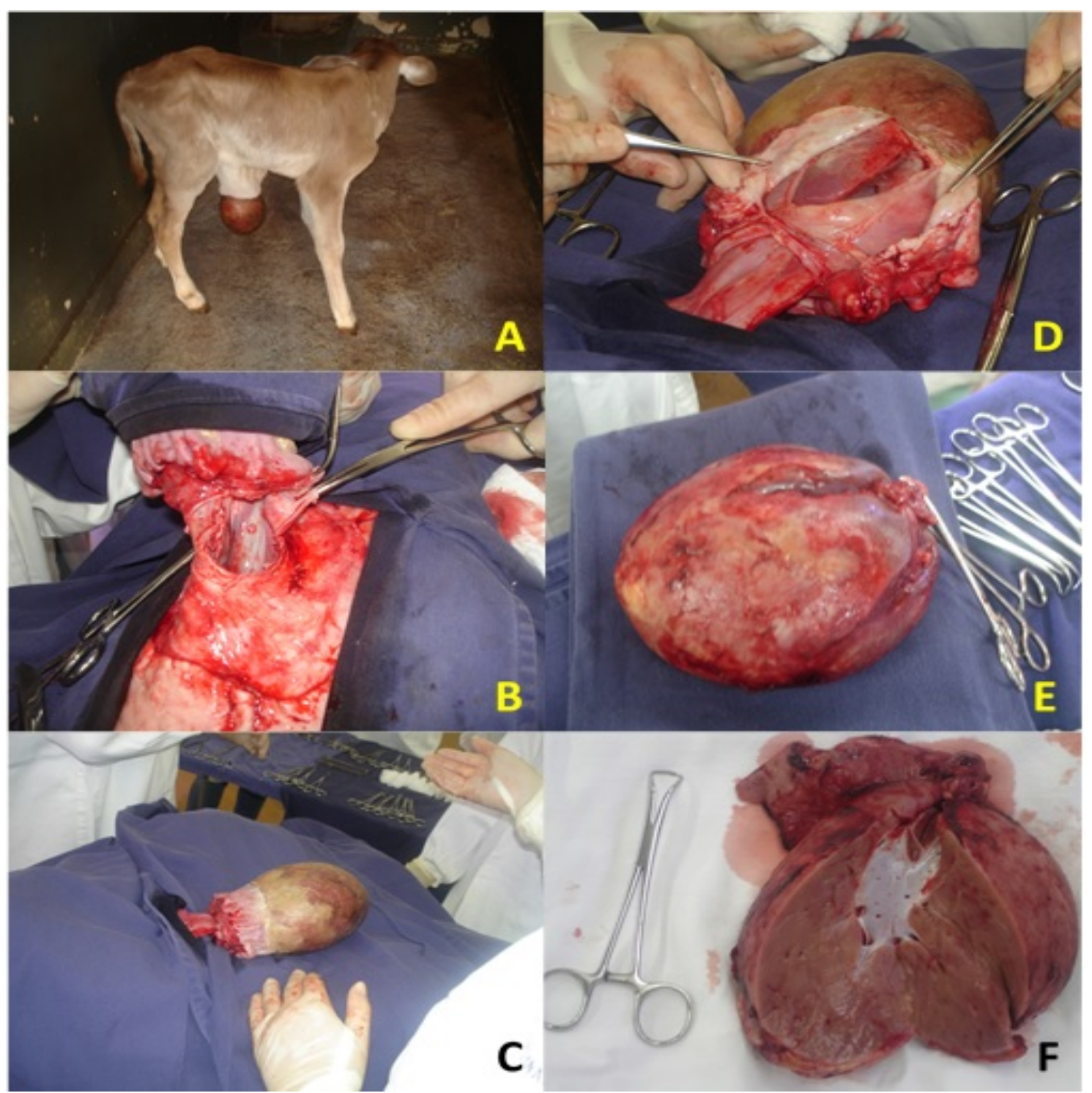

Figure 1. A) Photographic image of calf with increased volume in the umbilical region, suggesting an omphalocele. B) Elliptical incision around the volume increase with visualization of the content. C) Mass covered by the membrane connected to the abdominal cavity by a large vessel. D) Incision of the membrane covering the content and it's visualization. E) Content resected and without the covering membrane. F) Longitudinal incision of the content with macroscopic aspect suggesting that this is hepatic parenchyma, confirmed by histopathology.

The postoperative treatment consisted of antibiotic therapy with application of ceftiofur (Top Cef, Eurofarma, Brazil), (4mg/kg/SID/IM/7 days), anti-inflammatory therapy using flunixin meglumine (Banamine, Intervet, Brazil), $(1 \mathrm{mg} / \mathrm{kg} / \mathrm{SID} / \mathrm{IM} / 3$ days $)$, and topical daily dressing of the wound with $2 \%$ povidone-iodine solution. Fifteen days after the surgical procedure, there was herniaria recurrence and surgical wound contamination with the presence of mucopurulent discharge. The calf was subjected to surgical reintervention after which the abdominal wall was sutured using the same standard and suture wire. After 10 days, skin healing was visible and the surgical stitches were removed. 
The histopathological examination of the harvested fragment confirmed that it was hepatic parenchyma.

\section{DISCUSSION}

Omphaloceles have been reported in several species, including humans (Dunn and Fonkalsrub, 1997, Ardeleanu et al, 2013, Akinkuotu et al, 2015), cattle (Baird, 1993; Mee 1994, Vidya Sagar et al, 2011), horse (Steinman et al, 2000), pig (Camon et al, 1990), cat (Camon et al, 1990), and dog infants (Johnston et al, 1989; Camon et al, 1990). In humans, it is often associated with other anomalies and, in addition to the intestine, other organs of the abdominal cavity may be involved, significantly increasing morbidity and mortality (Wesley, 1997). In contrast, in most cases reported in calves, no other abnormalities were found (Baird, 1993; Mee 1994). Agreeing with the statements of Baird (1993) and Mee (1994), the bovine female in this study did not present any other anomaly associated with the omphalocele.

An omphalocele is a defect in the abdominal wall, at the insertion of the umbilical cord, with herniation of the abdominal organs, the majority of which occur in females (74\%), as in this report (Mee, 1994).

All abdominal organs can herniate, the most frequent protrusion being of the intestinal loops, stomach, and liver. The embryogenesis of omphalocele is not well understood. Various theories have been suggested to clarify its origin. Mustafa et al (2001) associated cases of omphalocele with extensive liver herniation and intestinal loops as a result of disruption in the development of lateral flaps and failure in the closure of the wall, around the third or fourth week of embryonic life. In the present study the calf presented an extensive omphalocele, whose content was composed of the liver covered with amniotic membrane, corroborating the statements of these authors.

After identification of the problem, surgical treatment must be immediate, before infection or tissue damage occurs and is therefore essential for survival (Kliegman and Behrman, 1987). With the surgical procedure, performed on the second day of life of the animal in question, the treatment was a success. Care was taken to discard the content rather than return it to the abdominal cavity in order to avoid possible contamination. In humans, despite improvements in surgical techniques and neonatal intensive care, the mortality of children with omphalocele ranges from 13 to 40 percent (Dunn and Fonkalsrub, 1997).

A clinical evaluation was performed four months after the second surgery and the heifer was found to be in good health and presenting normal development for its age.

Despite the high mortality rate in calves during the transurgical $(9 \%)$ and postoperative periods (36\%), reported by Mee (1994), the treatment instigated was satisfactory, even with the need for surgical intervention due to infection in the operative site.

\section{CONCLUSION}

In conclusion, omphalocele may contain liver. Ectopic liver is an extremely rare condition. The surgical treatment in the presented case focused on umbilicus with exploration of the abdominal cavity appeared to be sufficient.

\section{REFERENCES}

AKINKUOTU, A.C.; SHEIKH, F.; OLUTOYE, O.O. et al. Giant omphaloceles: surgical management and perinatal outcomes. J. Surg. Res., v.198, p.388-392, 2015.

ARDELEANU, V.; GEORGESCU, C.; FULGA, I. Major omphalocele with liver protrusion, liver dysmorphism: a case study. Rom. J. Morphol. Embryol., v.54, p.423-426, 2013.

BAIRD, A.N. Omphalocele in two calves. J. Am. Vet. Med. Assoc. v.202, p.1481-1482, 1993.

CAMON, J.; SABATE, D.; FRENCH, J. et al. Associated multiple congenital malformations in domestic animals: contribution of four cases. $J$. Vet. Med., v.37, p.659-668, 1990.

DUNN, J.C.Y.; FONKALSRUB, E.W. Improved survival of infants with omphalocele. Am. J. Surg., v.173, p.284-287., 1997.

JOHNSTON, S.D.; BUOEN, L.C.; WEBER, A.F. et al. Triploidy $(117, \mathrm{XXX})$ in a stillborn canine pup conceived with frozen semen. J. Am. Vet. Med. Assoc., v.194, p.1446-1448., 1989. 
KLIEGMAN, R.M.; BEHRMAN, R.E. The umbilicus. In: BEHRMAN, R.E.; VAUGHAN, V.C. (Eds.). Nelson textbook of pediatrics. Philadelphia: W.B. Saunders, 1987. p.415-416.

KO, J.C.H.; EVANS, L.E.; HAYNES, J.S. Multiple congenital defects in a female calf: a case report. Theriogenology, v.34, p.181-187, 1990.

MEE, J.F. Omphalocele in aborted and full-term dairy calves: a case series. Theriogenology, v.42, p.1125-1131, 1994.

MOORE, K.L. Malformations of the midgut. In: (Ed.). The developing human. Philadelphia: W.B. Saunders, 1988. p.231-234.

MUSTAFA, S.A.; BRIZOT, M.L.; CARVALHO, M.H.B. et al. Onfalocele: prognóstico fetal em 51 casos com diagnóstico pré-natal. Rev. Bras. Ginecol. Obstet., v.23, p.3137, 2001.
STEINMAN, A.; KELMER, G.; AVNI, G. Omphalocele in a foal. Vet. Rec., v.146, p.341343, 2000.

VIDYA SAGAR, P.; VADE K. S.; SAI KRISHNA, K.S. et al. An omphalocele in a buffalo calf: a case report. Buffalo Bull., v.30, p.10-11, 2011.

WESLEY, J.R. Omphalocele. In: GREENFIELD, L.J.; MULHOLLAND, M.W.; OLDHAM, K.T. et al. (Eds.). Surgery: scientific principles and practice. 2.ed. Philadelphia: Lippincott-Raven, 1997. p.2029-2032. 